Available online at www.journal.unrika.ac.id

Jurnal KOPASTA

Jurnal KOPASTA, 2 (2), (2015) 18-21

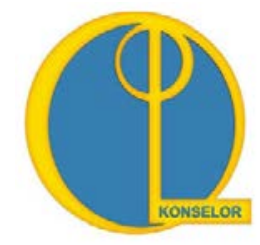

\title{
Hubungan Antara Penerapan Disiplin dengan Bolos Belajar Siswa di SMP Negeri 9 Batam
}

\author{
Ahmad Yanizon*, Ayurus Akhirini* \\ Division of Counseling and Guidance, University, of Riau Kepulauan, Batam
}

\begin{abstract}
Abstrak
Berdasarkan hasil analisis data terhadap penelitian di SMP Negeri 9 Batam tentang hubungan antara penerapan disiplin dengan bolos belajar, terbukti bahwa ada korelasi positif antara penerapan disiplin dengan bolos belajar. Hasil analisis tersebut menunjukkan bahwa terdapat hubungan yang kuat antara penerapan disiplin dengan bolos belajar.
\end{abstract}

Kata kunci: Disiplin, Bolos Belajar

\section{Pendahuluan}

Dunia pendidikan di Indonesia masih menghadapi beragam permasalahan, salah satunya adalah masalah siswa bolos belajar. Masalah bolos belajar terjadi hamper merata di seluruh Indonesia. Haluankepri.com pada Kamis, 09 Februari 2012, memberitakan kasus bolos belajar yang terjadi di Batam. Disebutkan bahwa terdapat 38 siswa, terdiri dari siswa SD, SMP, dan SMA yang terjaring razia sedang bolos belajar di Kecamatan Batam Kota dan Bengkong. Satu minggu sebelumnya, masih di Haluankepri.com edisi 01 Februari 2012, juga diberitakan tentang 34 siswa SD, SMP, dan SMA yang terjaring razia sedang bolos belajar di wilayah Kecamatan Sagulung.

Lebih lanjut, di dalam Undang-undang Sisdiknas Pasal 3 juga telah ditetapkan tujuan pendidikan nasional Indonesia, yaitu untuk berkembangnya potensi siswa agar menjadi manusia yang beriman dan bertakwa kepada Tuhan Yang Maha Esa, berakhlak mulia, sehat, berilmu, cakap, kreatif, mandiri. dan menjadi warga Negara yang demokratis serta bertanggungjawab (Sisdiknas, 2011: 11-12). Oleh karena itu para siswa tentunya diharapkan untuk menempuh pendidikan dengan maksimal untuk mendapatkan hasil yang diharapkan tersebut, bukan menghindari proses belajar dengan cara bolos. Apalagi diketahui bahwa perilaku bolos mungkin berkorelasi dengan meningkatnya permasalahan dalam kehidupan dewasa, termasuk kebutuhan bantuan psikiater, tingkat kejahatan tinggi, dan tingkat yang lebih tinggi dari kematian dini (Baker, Sigmund \& Nugent, Berg \& Jackson, Flakrieska-Praquin, Lindstrom \& Gillberg dalam Zimcheck, 2009: 10). Salah satu kemungkinan terburuk lainnya adalah siswa putus sekolah. Slavin (2008: 121) mengemukakan bahwa di antara faktor-faktor yang menyebabkan putus sekolah adalah kehadiran yang jelek. Adapun tujuan dari penelitian ini adalah untuk mendeskripsikan : 1) Perilaku bolos belajar siswa di SMP Negeri 9 Batam; 2) Penerapan disiplin di SMP Negeri 9 Batam; 3) Hubungan penerapan disiplin terhadap perilaku bolos belajar siswa di SMP Negeri 9 Batam.

*Ayurus Akhirini Telp 081276112933 E-mail address : gurubkriri@gmail.com

* Ahmad Yanizon Tel. 0853553885559 E-mail address : konselor.nizon@gmail.com 


\section{Metode Penelitian}

Penelitian ini adalah penelitian kuantitatif, yaitu penelitian dengan data berbentuk angka (Siregar, 2013: 15). Untuk mengumpulkan data peneliti menggunakan angket dengan skala Likert. Populasi dalam penelitian ini adalah siswa kelas IX di SMP Negeri 9 Batam sebanyak 271 siswa. Sedangkan untuk menentukan ukuran sampelnya, Sugiyono (2010: 86) menjelaskan jumlah sampel tergantung pada tingkat ketelitian atau kesalahan yang diinginkan oleh peneliti. Untuk penelitian ini, peneliti menggunakan teknik Solvin (Siregar, 2013: 61). Berdasarkan teknik Solvin dengan tingkat kesalahan 10\%, diperoleh jumlah sampel sebanyak 77 siswa. Penelitian ini memiliki dua variabel, yaitu penerapan disiplin dan bolos belajar.

\section{Hasil Penelitian}

Hasil penelitian tentang penerapan disiplin, diperoleh data skor tertinggi 113 dan skor terendah 75, dengan skor rata-rata 101,95. Sedangkan skor persentase untuk setiap indicator adalah: 1) Tepat Waktu 10.4\%; 2) Mengikuti KBM dari awal sampai selesai 57.1\%; 3) Masuk sekolah setiap hari sekolah 10.4\%; 4) Mengikuti semua kegiatan yang diwajibkan sekolah diluar KBM 25.9\%; 5) Meminta izin guru piket untuk meninggalkan sekolah pada jam belajar efektif $15.6 \%$; 6) Teguran 5.2\%; 7) Surat Peringatan 5.2\%; 8) Pemanggilan orangtua $10.4 \%$; 9) Skorsing 5.2\%; 10) Penghargaan prestasi perlombaan 5.2\%. Pada hasil penelitian tentang bolos belajar, diperoleh skor tertinggi 132 dan skor terendah 103, dengan skor rata-rata 124,92. Sedangkan skor persentase untuk setiap indicator adalah: 1) Bolos satu hari penuh 25.9\%; 2) Bolos setelah jam istirahat 20.8\%; 3) Bolos pada mata pelajaran tertentu 15.6\%; 4) Tidak hadir tanpa keterangan10.4\%; 5) Meninggalkan sekolah pada jam pelajaran efektif tanpa izin15.6\%; 6) Membuat surat keterangan izin palsu 15.6\%; 7) Berpura-pura sakit 10.4\%; 8) Meninggalkan kelas setelah absensi 15.6\%; 9) Beraktivitas selain belajar masih di lingkungan sekolah 10.4\%; 10) Main di warung internet 10.4\%; 11) Beraktivitas dengan geng diluar teman sekolah 20.8\%.

\section{Pembahasan}

Melalui analisis korelasi Product Moment menggunakan SPSS 17.00, diketahui bahwa nilai signifikan antara penerapan disiplin dengan bolos belajar adalah 0,000. Berarti terdapat hubungan antara penerapan disiplin dengan bolos belajar. Hal tersebut didasarkan pada criteria keputusan pengujian hipotesis, yaitu: 1) Tolak Ho dan terima Ha bila probabilitas (Asym.Sig) < 0.05; 2) Terima Ho dan tolak Ha bila probabilitas (Asym.Sig) $>$ 0,05. Van Breda (dalam Balainakorodawa, 2009: 18) menjelaskan bahwa terdapat studi dan kriteria yang membedakan antara bolos yang dilakukan sepanjang hari dan bolos pada beberapa mata pelajaran bahkan bolos tanpa meninggalkan lingkungan sekolah sama sekali. Pada penelitian ini, sebagaimana yang terlihat pada tabel 12 diketahui bahwa dilihat dari jenis bolos belajar, siswa yang bolos cenderung lebih banyak memilih bolos satu hari penuh (25.9\%) diikuti dengan bolos setelah jam istirahat (20.8\%) dan bolos pada mata pelajaran tertentu (15.6\%).

Hurlock (1980: 125) menyebutkan ada tiga bentuk dalam penerapan disiplinya itu disiplin otoriter, disiplin yang lemah, dan disiplin demokratis. Disiplin demokratis merupakan bentuk penerapan disiplin yang menyeimbangkan antara pemberian hukuman dan penghargaan yang betul-betul disesuaikan dengan kondisi perilaku siswa serta disertai dengan penjelasan dan kebebasan berpendapat. Berdasarkan peraturan sekolah dan wawancara dengan Kepala Sekolah SMP Negeri 9 Batam, diketahui bahwa SMP Negeri 9 Batam menerapkan bentuk disiplin demokratis. Untuk ancaman hukuman, kecemasan tertinggi siswa adalah pada poin pemanggilan orang tua yang mencapai 10.4\%, yang kemudian diikuti dengan teguran, surat peringatan dan skorsing masing-masing dengan persentase 5.2\%. Keys (dalam Balainakorodawa, 2009: 28) dalam penelitiannya pada struktur SMP di Afrika Selatan menemukan bahwa sekolah dengan tingkat bolos yang tertinggi adalah sekolah yang paling kaku dalam kebijakan yang berkaitan dengan kehadiran. Sedangkan Suhid et.al (2012: 347) melalui penelitiannya mengungkapkan bahwa salah satu faktor di sekolah yang dapat mempengaruhi perilaku bolos belajar siswa adalah peraturan sekolah yang kaku. Maka dapat dipahami bahwa memang untuk permasalahan bolos belajar siswa, penerapan disiplin perlu mendapat perhatian signifikan oleh semua pihak. Bagaimana menyusun peraturan sekolah yang akan diterapkan dapat menjadi langkah awal untuk dapat menerapkan disiplin dengan tepat, sebagaimana yang dikemukakan oleh Kiprop (2012: 127) bahwa siswa berkelakuan buruk karena peraturan sekolah tidak 
mendefinisikan secara jelas jenis perilaku yang benar atau salah dari mereka. Dalam sebuah penelitian tentang praktik disiplin yang efektif, ditemukan bahwa salah satu praktik yang tidak efektif mencakup aturan tidak jelas dan atau aturan tidak dapat diterapkan (Kiprop, 2012: 127).

\section{Kesimpulan}

Berdasarkan pada hasil pengolahan dan analisis data serta pembahasan tentang hubungan antara penerapan disiplin dengan bolos belajar siswa di SMP Negeri 9 Batam dapat disimpulkan: 1) Terdapat hubungan yang kuat antara penerapan disiplin dengan bolos belajar siswa; 2) Berkenaan dengan bolos belajar siswa, dilihat dari jenisnya, siswa cenderung lebih sering bolos satu hari penuh, diikuti oleh bolos pada jam pelajaran tertentu dan bolos setelah jam istirahat. Dilihat dari caranya, siswa cenderung lebih sering meninggalkan lingkungan sekolah pada jam pelajaran efektif, berpura-pura sakit, membuat surat keterangan izin palsu, diikuti dengan bolos pada jam pelajaran tertentu dan tidak hadir tanpa keterangan. Dilihat dari aktivitas saat bolos belajar, siswa cenderung lebih banyak menghabiskan waktu beraktivitas dengan geng di luar teman sekolah, diikuti dengan main di warnet, dan menghabiskan waktu di lingkungan sekolah tanpa mengikuti pelajaran; 3) Berkenaan dengan penerapan disiplin, masih sangat rendah dalam pemberian penghargaan kepada siswa. Untuk hukuman siswa cenderung mengkhawatirkan pemanggilan orang tua apabila terjadi pelanggaran.

\section{Daftar Pustaka}

Balainakorodawa, L. (2009). Causes of Truancy From Mainstream Education For A Group of Pasifika Students Enrolled In Alternative Education. Tesis. Diunduh 16/03/2013.http://aut.researchgateway.ac.nz

Depdiknas. (2011). Undang-undang RI Nomor 20, Tahun 2003 dan Penjelasannya. Jakarta: SL Media

Hurlock, E.B. 1980. Psikologi Perkembangan. Jakarta: Erlangga

Kiprop, C.J. (2012). Approaches to Management of Discipline in Secondary Schools in Kenya. Journal Moi University 2012. Diunduh 23/03/2013 http://www.academicjournals.org

Siregar, S. (2013). Statistik Parametrik untuk Penelitian Kuantitatif. Jakarta: Bumi Aksara

Slavin, R.E. (2008). Psikologi Pendidikan, Teori dan Praktik, Jilid I. Jakarta: PT. Indeks

Sugiyono. (2010). Metode Penelitian Kuantitatif, Kualitatif, dan R\&D. Bandung: Penerbit Alfabeta

Suhid, A.et al. (2012). Factors Causing Student Absenteeism According To Peers. Journal University Putra Malaysia, 2012. Diunduh 16/03/2013, dari http://jjlp.law.ucdavis.edu

Prayitno. (2009). Dasar Teori dan Praksis Pendidikan. Jakarta: Grasindo

Zimcheck, V.C. (2009). Student/School Conselor Ratios and School Attendance Rates: 
Review of Literature and a Correlational Study. Disertasi, Oregon State University,2009. Diunduh 16/03/2013, dari http://ir.library.oregonstate.edu 